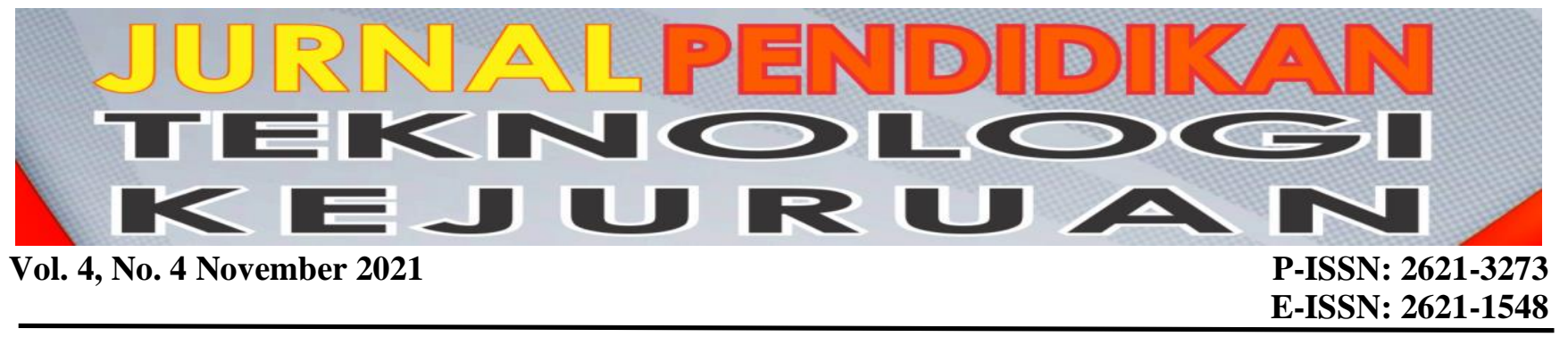

\title{
The Development of Movement System of The Second Six-Legged Robot PTE UNIMA
}

\author{
Calvin E. J. Mamahit ${ }^{1 *}$, Mildes Sanggola ${ }^{2}$ \\ ${ }^{1,2}$ Electrical Engineering Education, Faculty of Engineering, Universitas Negeri Manada \\ *Corresponding author, e-mail: calvinmamahit@unima.ac.id
}

\begin{abstract}
Engineering technology in robotics for the present era is no longer new, especially in high education, marked by Indonesian robot contests routinely held annually by the national achievement center. The participants in this event are groups of students from all higher education institutions spread throughout Indonesia. The development of robotics technology is now faster to spur individuals and students to compete to conduct research and development in robotics. The study aims to develop a six-legged robotic motion system or so-called hexapod. The research was conducted using the Addie model research method consisting of five stages, namely, analyze stage to analyze the needs of the development of the robotic motion system and analysis of the needs of tools and materials to be used. The design stage of designing the mechanical structure of the robot both in terms of hardware and in terms of robot software, the development stage of developing a six-legged robot's motion system to be more stable and more efficient in moving, the implementation stage is a test stage of the robot's motion system that has been developed. The evaluation stage is the last stage of this development research; at this stage, the evaluation is done to ensure the robot's motion system is feasible to use.
\end{abstract}

Keyword: hexapod, motion system of a legged robot, robot development, tripod gait

\section{INTRODUCTION}

The Indonesian Robot Contest (KRI) is a design and engineering competition in the field of robotics. KRI is organized by the National Achievement Center, Ministry of Education, and Culture of the Republic of Indonesia. This Indonesian Robot Contest can be participated by a team of students at universities registered with the Ministry of Education and Culture of the Republic of Indonesia and the Higher Education Database (Puspresnas, 2019). The Indonesian Robot Contest was first held in 1993 under the Indonesian Robot Contest (IRC), which the Surabaya State Electronics Polytechnic organized. Furthermore, in 2003 the Directorate General of Higher Education, Ministry of Education and culture, through the directorate of research and community service, began to fund the Indonesian robot contest. For a robot to provide high economic value, it must be designed for a particular purpose (special purpose) (Budiharto, 2006). A mobile robot (robot car) is a construction robot whose characteristic is to have actuators in the form of wheels or legs to move the entire robot body to move positions from one point to another (Darwison et al., 2011). One of them is a robot. The hexapod (legged robot) is a robot that is quite complex in its design and manufacture because it needs to consider several factors, including balance and speed (Halim, 2007).

Currently, robots are very diverse, especially for the type of legged robot; in this study, a six-legged robot or a hexapod robot is often called. To perform the movement, the hexapod robot is controlled using a microcontroller. Arduino microcontroller is an opensource single-board microcontroller derived from the Wiring platform designed to facilitate electronics in various fields. The hardware has an Atmel AVR processor, and the software has a programming language called processing (Kadir, 2013); in the manufacture of this robot it focuses on developing a robotic propulsion system, mainly in the software and hardware parts, this development is needed because in the previous robot there are still many The main shortcomings in the robot are in the robot motion system, these shortcomings include the type of servo motor used as a robot mover, the robot frame structure, voltage supply and programming on the robot.

Several studies that are relevant to the development of a six-legged robotic motion system include research conducted by Ahmad Wahyu Tri Utama 
entitled the development of a six-legged robot system (Hexapod) using the behavior base control method in the Indonesian fire-fighting robot contest (Utama, 2018), research conducted by Muhamad Fajar Ramadhan with the title design stability control of a hexapod robot using the Neuro-Fuzzy method (Ramadhan, 2017), and research conducted by Darwison and Rian Wahyudi with the title speed control of fire extinguishing hexapod robot using the fuzzy logic method (. \& Wahyudi, 2015).

The purpose of this study was to analyze the development of a six-legged robot motion system. The robot motion system that is made is expected to run well both in terms of software and hardware.

\section{METHOD}

This type of research is development research, ADDIE model (Analysis-Design-DevelopmentImplementation-Evaluation). This model was developed by Molenda and Reiser. This model is often used to describe a systematic approach to instructional development. Molenda stated, "I am satisfied at this point to conclude that the ADDIE model is merely a colloquial term used to describe a systematic approach to instructional development, virtually synonymous with instructional systems development (ISD)" (Molenda, 2003). In addition, Molenda also said that the ADDIE model is a general learning model and is suitable for development research. When used in the development, this process is considered sequential but also interactive (Molenda, 2003).

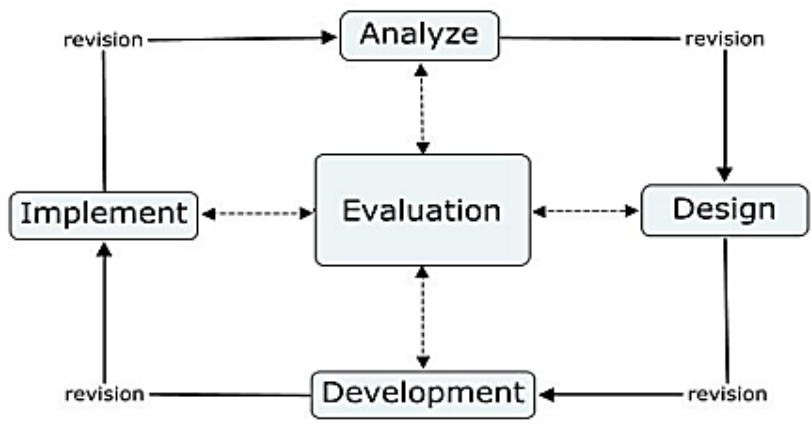

Figure 1. Research flow block diagram

The following is an explanation of the ADDIE development stage that researchers will do.

\section{A. Analysis}

The analysis stage is the stage where researchers analyze the need to develop a six-legged robot motion system. The stages of analysis carried out by the author include:
1. Analysis of robotic motion system development needs

2. Analysis of the availability of resources such as software, programmers, infrastructure, and tools that will be used in this development research

3. Literature review (theory, other research, and system components)

\section{B. Design}

The second stage of the ADDIE model is the design stage. The first stage is the design of the robot hardware, the design of the robot hardware including the block diagram of the system that will be used on the robot, the schematic of the system, in this case, the connection description of each component that will be used in the robot. The second stage is making a flowchart, a diagram of a process that describes the sequence of the program running from the robot starting to be active until the robot starts to move.

\section{Development}

The development stage is the product realization stage. At this stage, the development of the robot motion system is carried out according to the design to make a six-legged robot. The next step is programming the robot using the Arduino IDE software. After the robot and the motion system program for the robot have been completed, the next step is to enter the program into the microcontroller to calibrate the robot.

\section{Implementation}

The fourth stage is implementation. After the robot and the motion system program for the robot have been developed, the next step is to enter the program into the microcontroller to move the robot.

\section{E. Evaluation}

At the evaluation stage, the robot motion system is tested to ensure that the developed robot motion system runs according to the design and there are no errors. Evaluation is also carried out by technical experts in the field of robotics.

\section{F. Data Collection Techniques}

In doing this final project, the data collection techniques used for the development of this sixlegged robotic motion system are as follows:

1. Literature study needs development of robotic motion systems.

2. analysis of the design and motion system of a sixlegged robot.

3. To design the shape of the robot frame and the robot motion system that will be used. 
4. analysis of the availability of material resources and tools that will be used to develop a six-legged robot motion system.

5. Existing hardware testing to determine the normal function or not.

6. Programming or making software for performance on the system created.

7. Conducting hardware testing with programs that have been made to determine the performance of the six-legged robot motion system.

\section{RESULT \& DISCUSSION}

A. Analysis

The analysis stage is the initial stage of developing a six-legged robotic motion system, which is carried out. Before starting the design and manufacture of this system, it is necessary to analyze what needs must be met so that it can be made as expected.

At the initial stage, the researchers conducted a development needs analysis by analyzing the previous robots included in the Indonesian firefighting robot contest in 2020. The analysis was carried out based on the data obtained when participating in the contest where the robot had not been able to complete the mission in the first and second sessions of the contest. Analysis of development needs is carried out in two stages: analyzing the robotic drive system or control system and analyzing the structural and mechanical robots.

The first analysis was carried out, namely the analysis of the control system and robot drive; the robot was controlled using 16 PWM control board channels connected to the ATmega2560 microcontroller (Brandenbourger et al., 2019), the first robot that was included in KRI 2020 used 12 MG996R servo motors with a maximum torque of 12 $\mathrm{kg}$ with an operating voltage of $4.8-7.2 \mathrm{~V}$ servo is placed as many as two pieces on each leg of the robot which serves as a joint for the robot mover. In the analysis carried out on the robotic drive system, it was found that the amount of torque produced by each leg of the robot was irregularly caused by the unstable voltage supply entering each driving motor. This irregular torque causes the movement of the robot's legs to become unstable and often experiences errors where the robot's legs move not according to what is programmed in the coding.

Analysis was also carried out on the mechanical structure and framework of the robot. It was found that the robot's construction was not sturdy because the frame material was only made of thin acrylic. Furthermore, the structure of the robot is not precise, so that when the robot is operating. The robot's movement becomes unstable and causes the torque load generated by each leg to be uneven.
1. Result of the analysis of the need for tools and materials

The stage of analyzing the needs for tools and materials aims to determine the needs, tools, and materials used later in the development of the robot motion system. This stage is divided into two: analysis of robot hardware requirements and analysis of robot software requirements.

2. Hardware requirement analysis

At this stage, the researcher analyzes all the hardware components of the robot and the tools that will be used to design the robot later.

3. Software requirements analysis

At this stage, the researcher analyzes the needs of design software and programming software used to create a coding program on the robot.

\section{B. Design}

1. System block diagram design

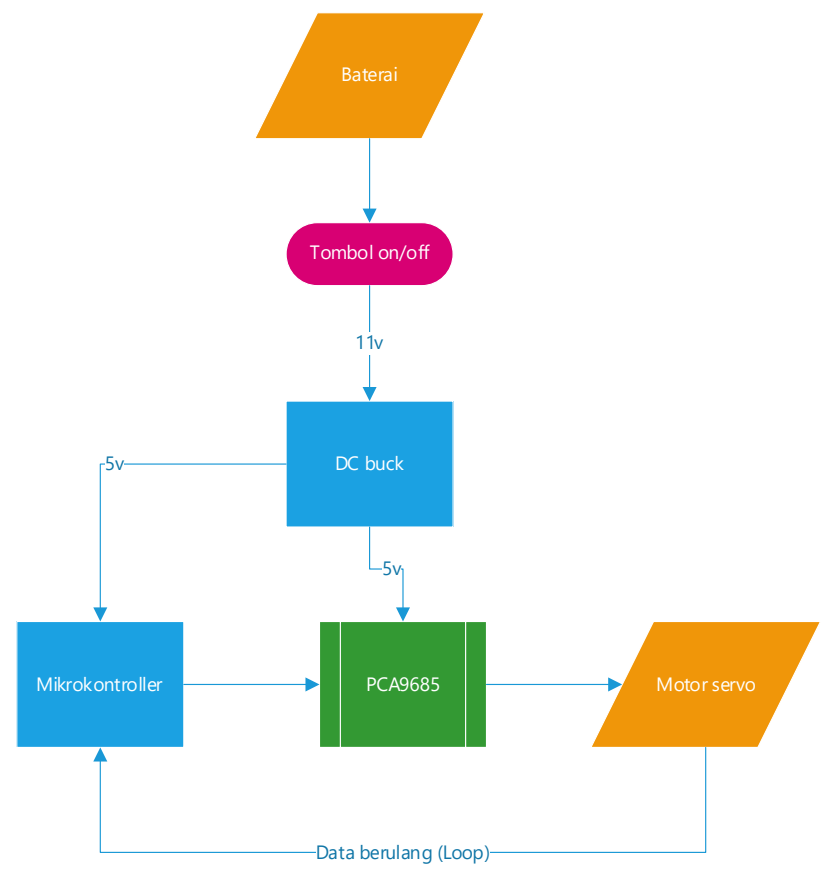

Figure 2. System block diagram.

This block diagram represents the operation flow of the robot, starting with the input voltage from the battery of 11 volts DC which is connected to the on/off switch to operate and turn off the robot (Akhtaruzzaman et al., 2009); the 11-volt voltage is then converted to 5 volts DC by the DC buck converter, the 5-volt voltage is used to operate the microcontroller and servo driver, after that the microcontroller will work to process the coding program data that has been inputted to operate the motor driver used to control multiple servo motors, the servo motor control command is a loop command where the command will be executed repeatedly, where the robot will continue moves with the current 
program until the on/off switch is positioned in the off position.

2. Schematic of the power supply circuit

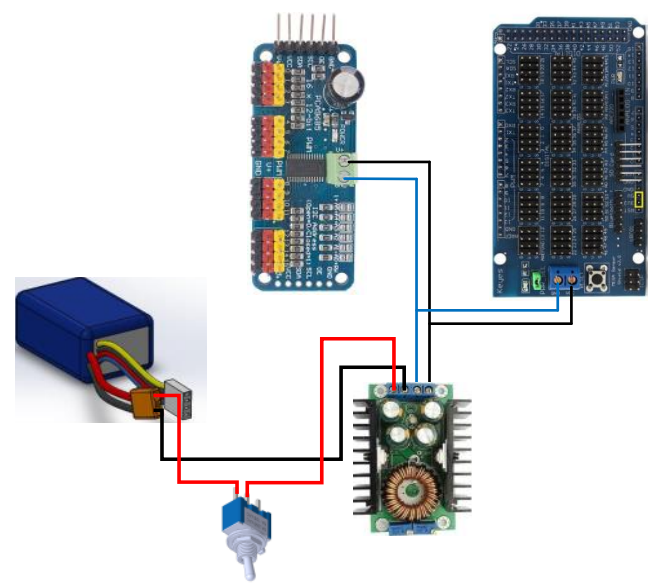

Figure 3. Schematic of the power supply circuit

3. Arduino schematic to Arduino shield sensor

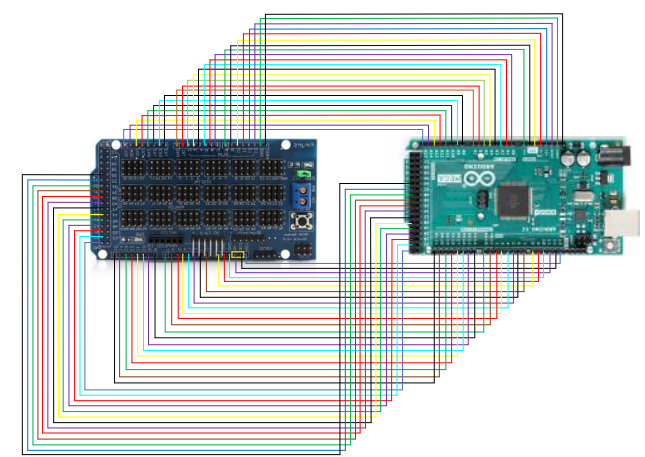

Figure 4. Schematic of Arduino connection to sensor shield

4. Schematic connection of PCA9685 to Sensor shield Arduino

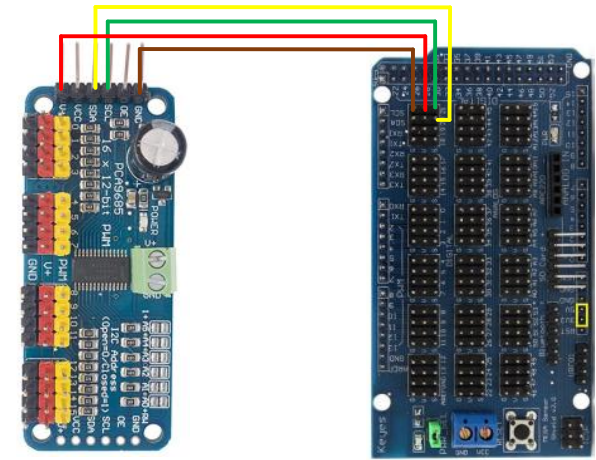

Figure 5. Schematic of connection of PCA9685 to sensor shield

5. Servo connection schematic to PCA9685

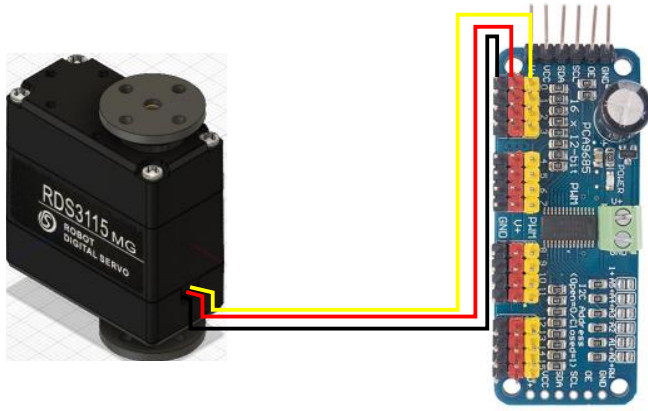

Figure 6. Schematic of servo connection to PCA9685

\section{Development}

The first step taken at this stage of development is to make a six-legged robot following the design or design that existed in the previous stage.

\section{Robot frame structure}

The design of the hexapod robot frame consists of a rigid body with six right feet, and each leg has an independent behavior (Maulana, n.d.). The robot frame in this study was made of acrylic material with $5 \mathrm{~mm}$ teal, which was made based on a predetermined design. The robot frame consists of two parts, namely the lower and upper frames; the two frames are connected using a dual head type servo motor, as shown in the following figure.

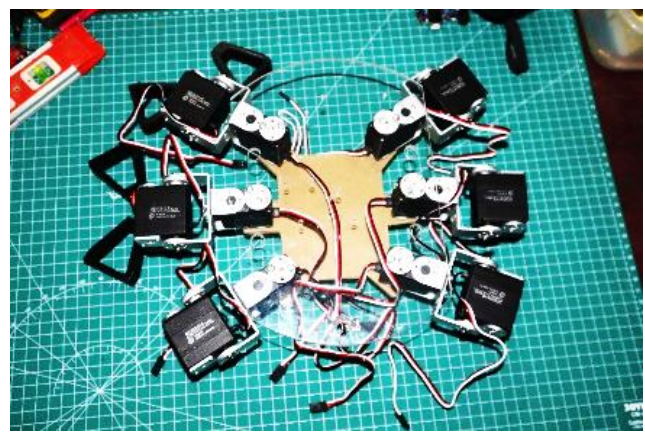

Figure 7. Servo motor mounted on the robot frame

\section{Installation of robot components}

The position of each robot component is installed according to the position that has been determined in the design software, and this is done because, in the previous robot, all components installed in the robot did not pay attention to the balance of weight on each of the existing components. Therefore, in this study, the placement of the robot components was previously determined using the software, as shown in the following figure. 


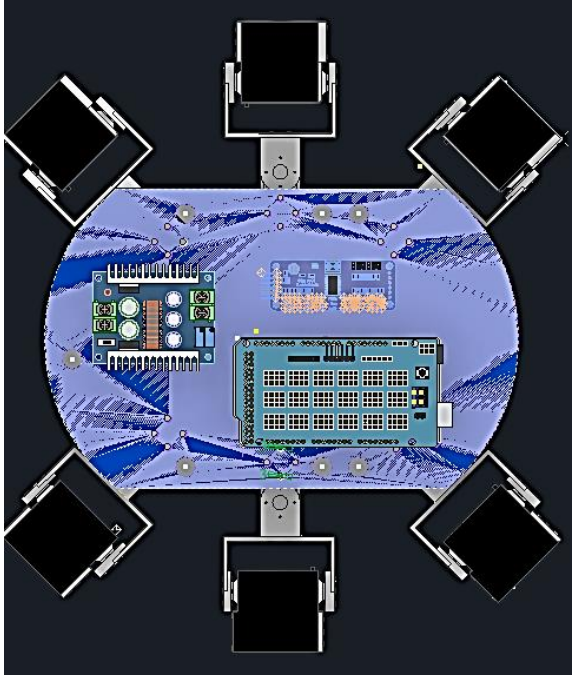

Figure 8. The layout of robot components

\section{Making robot program coding}

After the mechanical structure and all components of the robot are installed, the next step is to code the program for the robot, which will then be entered into the robot's micro controller (Zhang et al., 2016). The first step in coding the program is to enter the library of each component into the Arduino IDE software. The libraries include the sensor shield library, the PCA968 library, and the cable connection library from the Arduino to the motor driver. These libraries can be seen in the following image.
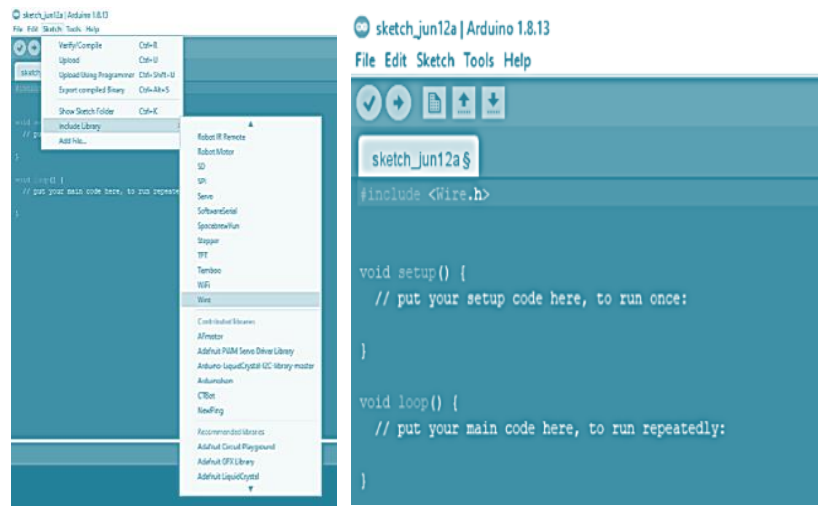

Figure 9. Arduino cable connection library to driver
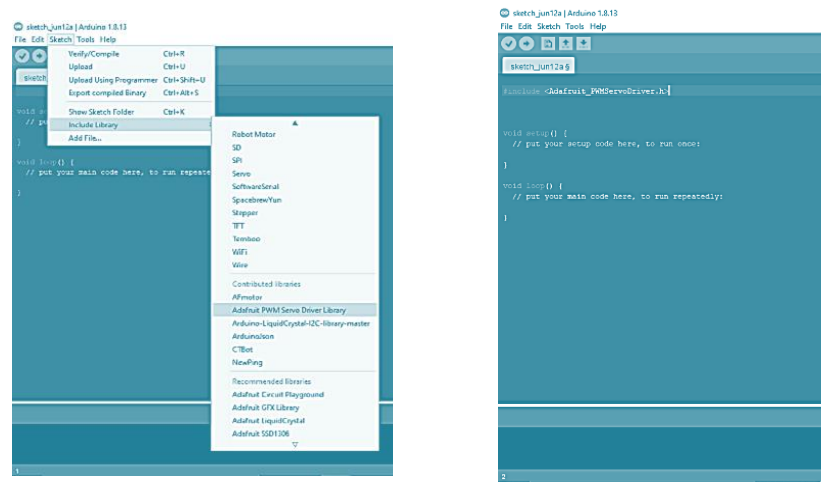

Figure 10. Library PWM servo driver
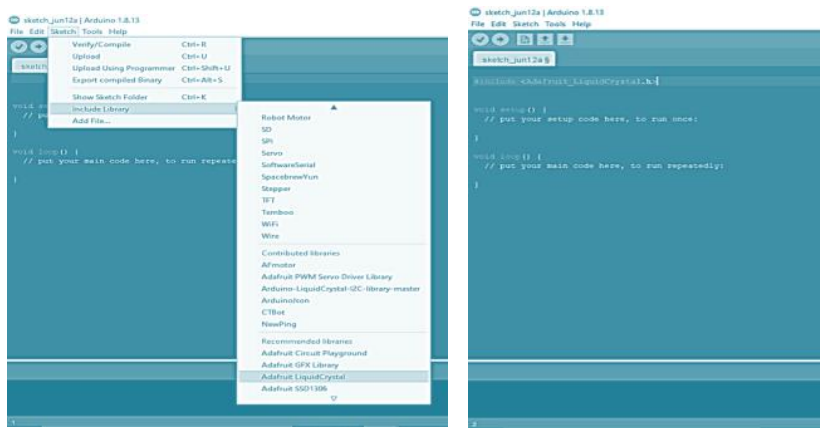

Figure 11. Sensor shield library

After all the libraries have been entered into the Arduino IDE software, the next step is to code a program to calibrate each leg. The code for the program to calibrate each leg of the robot can be seen in the following figure.
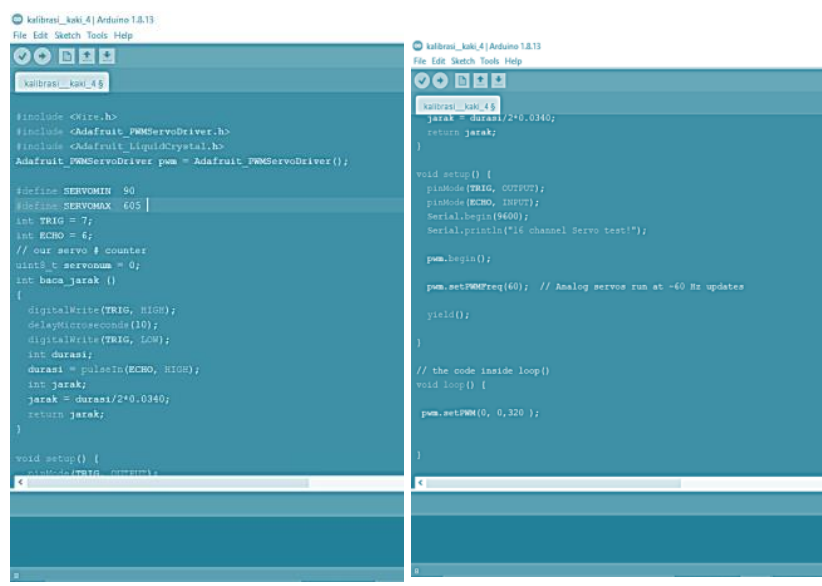

Figure 12. Robot leg calibration program coding

\section{Implementation}

This implementation stage is the stage where the mechanical structure and robot software programs are combined. At the implementation stage, it is divided into several parts, including determining the robot's initial position, the principle of movement of the six-legged robot, and how the robot moves (Chen et al., 2019).

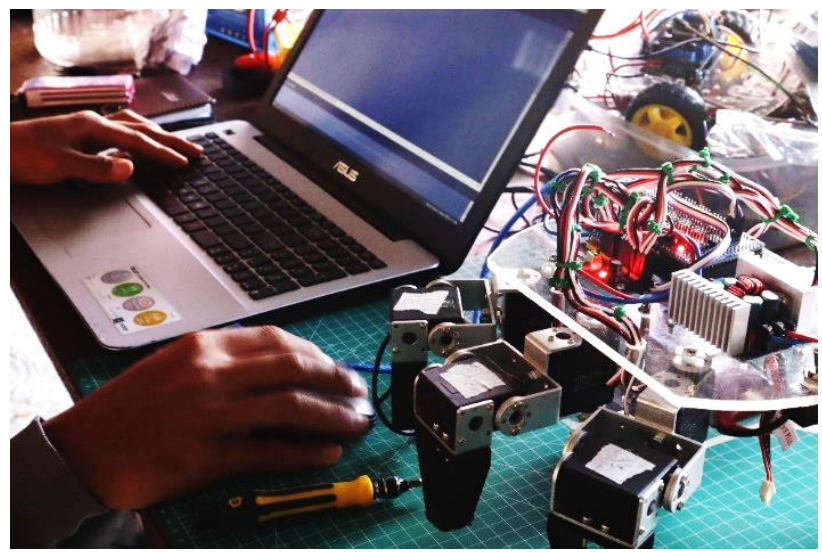

Figure 13. The process of uploading the program code into the robot 


\section{Robot's starting position}

After the mechanical structure and calibration of the robot have been completed, the next step is to code the program based on the calibration data and then enter the code into the microcontroller, which will be used later to drive the robot (Burgard et al., 1997). Before entering the program code into the microcontroller to move each existing joint, the coxa and tibia joints on the robot leg must be positioned initially. To position the robot's legs in the initial position, the program code is entered as follows.

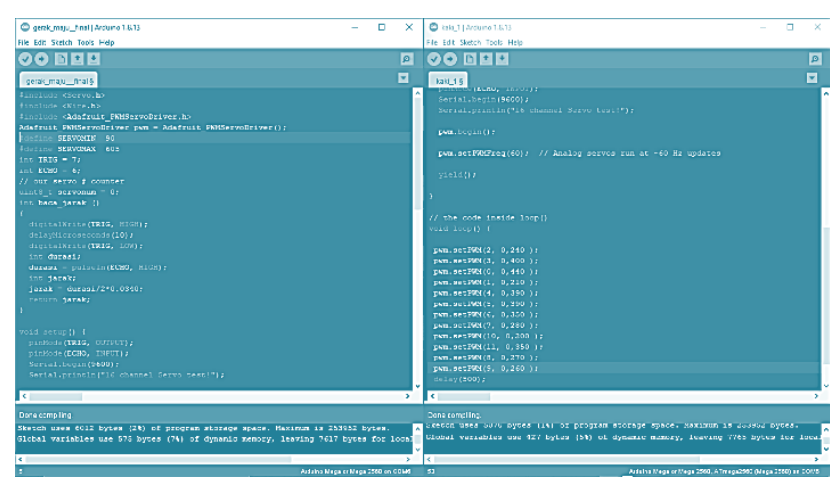

Figure 14. Coding for the robot's leg starting position

After the coding is uploaded to the microcontroller and the robot's power supply is turned on, the position of the robot's legs will appear, as shown in the following image.

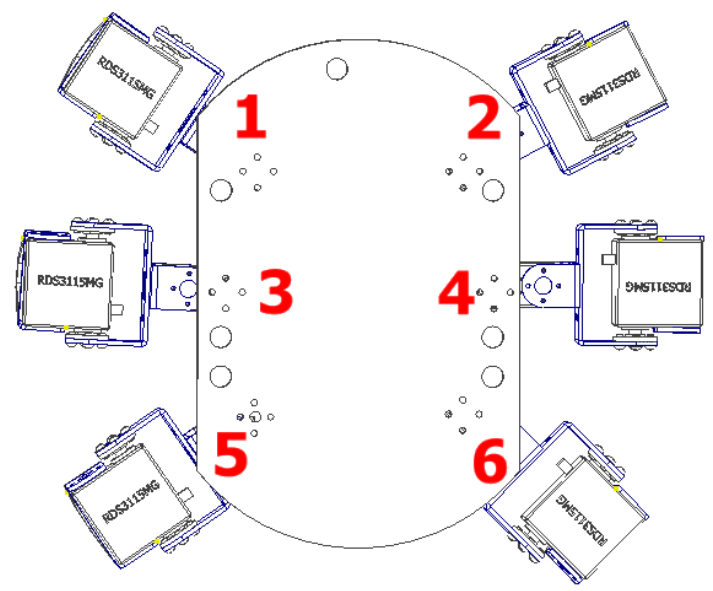

Figure 15. Robot's starting position

2. The principle of movement of the six-legged robot

The movement principle of this six-legged robot uses the tripod gait principle (Devjanin et al., 1983). To move the robot body, the movement of the robot's legs is grouped into two, the first legs, numbers 4,1 and 5, move simultaneously, and the second, legs number 3,2, and six, are made to move. Simultaneously, these two groups of legs are moved alternately with the movement time delay set in the coding program, the robot's legs are moved alternately so that the robot's balance is maintained, this is where the function of the tripod gait principle lies where when three legs start to move, the other three legs will move (Soyguder \& Alli, 2007). It serves as a tripod to support the robot body. The principle of the movement can be seen in the following code and image.

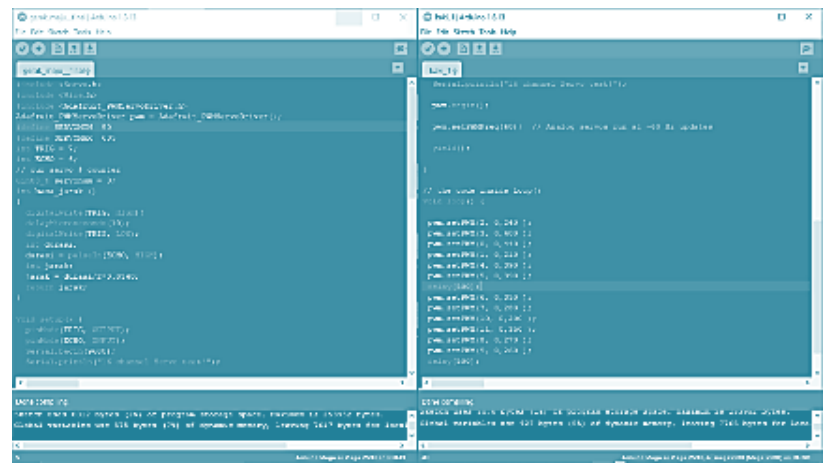

Figure 16. Program coding tripod gait robot movement

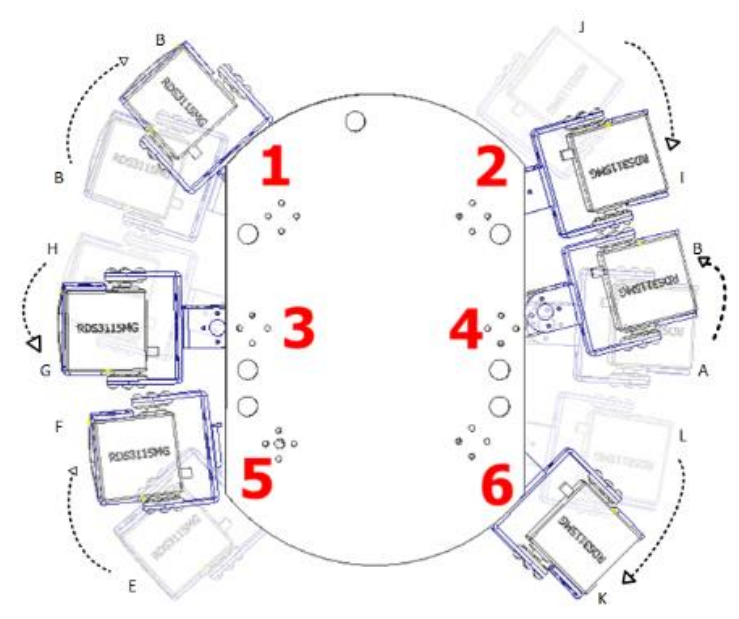

Figure 17. Robot gait tripod movement

Based on the picture, at the same time, legs number 4,1 , and 5 will lift and move according to the direction of the arrow in the picture. Legs 3,2, and 6 have not moved, according to the program code in the interval 500 microseconds, then the legs 3,2 , and 6 will start to move, along with the closeness of legs 4,1 , and 5 to the surface. With this movement, the mechanical legs of the robot will support each other.

\section{How the robot moves}

A combination of pulse or PWM signals is used to move the robot, which is obtained during calibration at the development stage. The combination of pulse or PWM signals is then implemented into a coding program which will later be used to move the robot (Sethi et al., 1992). The coding of the program and 
the resulting robot motion can be seen in the following figure.

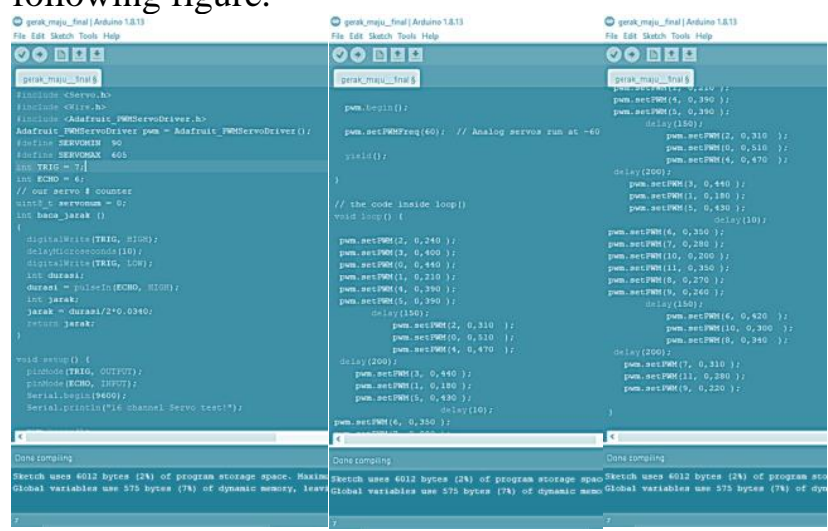

Figure 18. Robotic advance program coding

Based on this coding, the movement of the robot can be seen in the following picture:

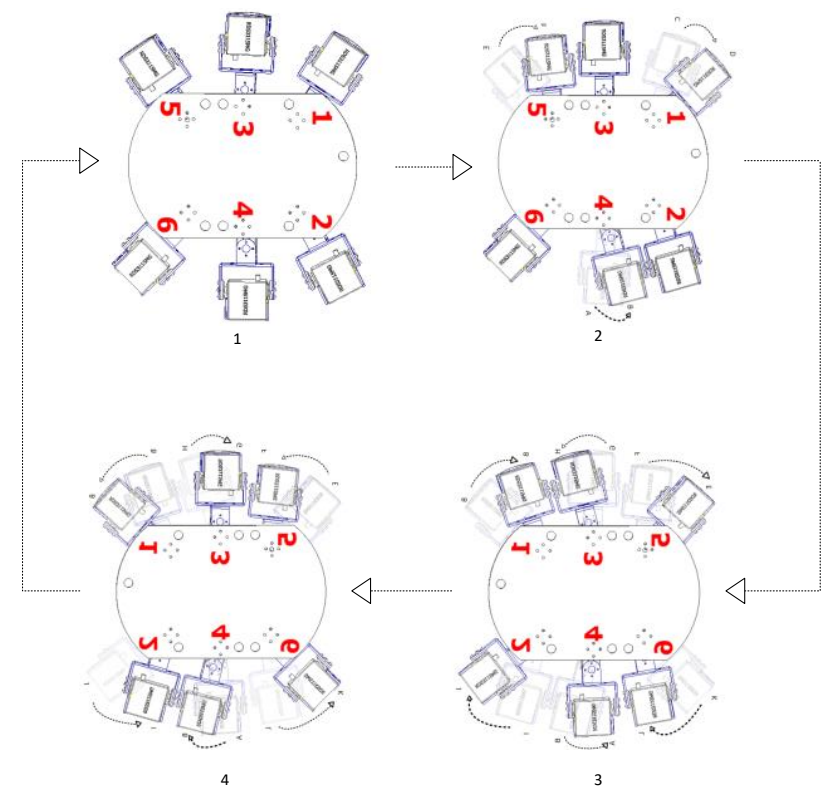

Figure 19. Moving robot process

The picture above shows how the robot process begins to move from position 1 to position two, then moves to position three, after which it moves to position 4 , with the same movement pattern as shown in the picture above. This movement pattern will continue to repeat until the robot is turned off because the coding of the robot program is made in a loop where the program commands that have been executed will be repeated from the beginning and so on.

\section{E. Evaluation}

The last stage of this development research is the evaluation stage. The evaluation is carried out by testing the reliability of the robotic motion system that has been developed; trials are carried out on the robot motion system in several different fields.

\section{Robot movement test}

The first test is to test the robot's motion system with the feet not touching any surface, and this test is carried out to determine whether or not the legs move that is not following the program code entered into the robot control system.

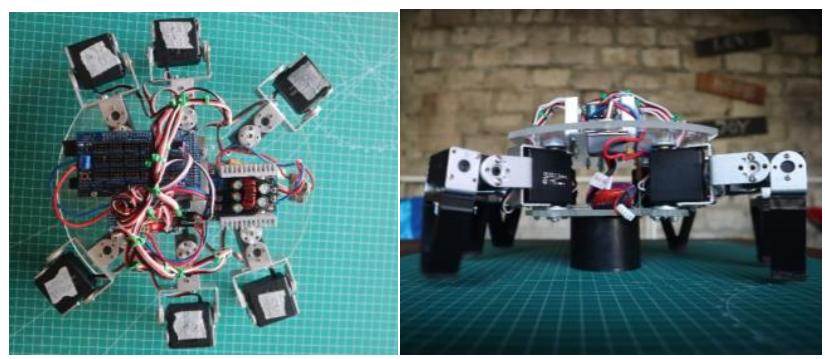

Figure 20. Robot movement test

At the first test, the input voltage used is the median value of the recommended input voltage range in the pca9685 datasheet; the recommended voltage range is 2.5-5.5 volts dc (Earl, 2019). therefore the first experiment used a 4-volt dc input voltage, but in this experiment, the robot's legs did not move according to the programming code entered into the microcontroller; the cause was that the voltage regulator on the servo driver burned out, this was because the input voltage on the driver was unable to move 12 servo motors simultaneously. After replacing the servo driver with a new one, the voltage input to the driver is the maximum recommended voltage on the datasheet, which is 5.5 volts dc. Using this maximum voltage, the driver can move 12 servo motors properly, and the robot's footwork follows the coded program inputted.

\section{Test on flat terrain}

This test was carried out on a flat multiplex surface, as shown in the following figure. 


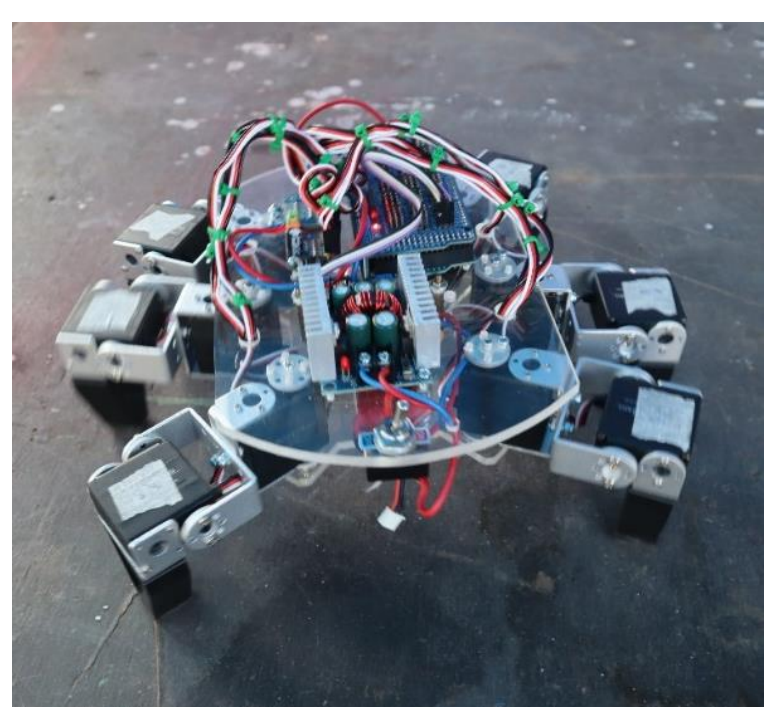

Figure 21. Robot testing on a flat surface

In this test, the robot can move very well according to the program coding inputted into the microcontroller. The movement of each leg of the robot is very stable and does not experience errors even though it moves for quite a long time.

\section{Robot testing on uneven terrain}

This test is carried out on a concrete surface that is uneven and has a rough surface, as shown in the following figure.

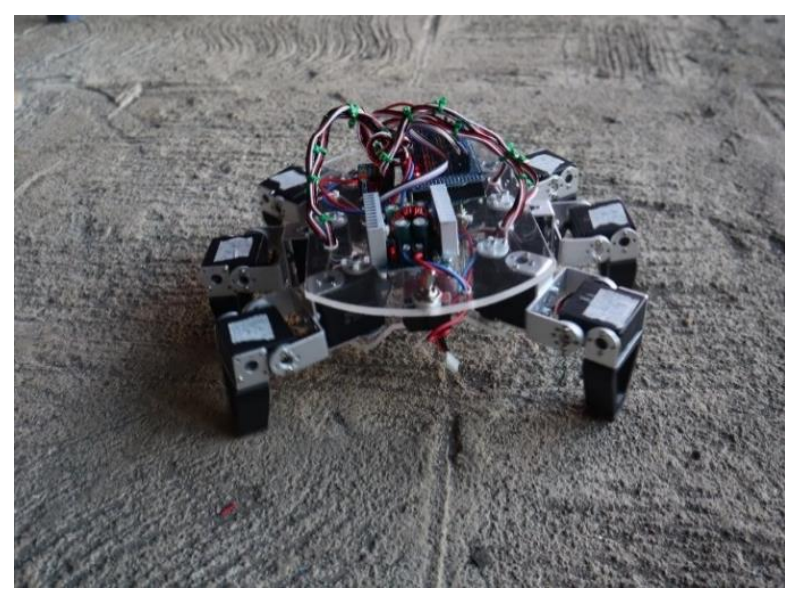

Figure 22. Robot testing on uneven terrain

In this test, the robot can move well, following the input coding program entered into the microcontroller.

\section{Test on flat and slippery terrain}

This test was carried out on a smooth, smooth ceramic floor surface, as shown in the following picture.

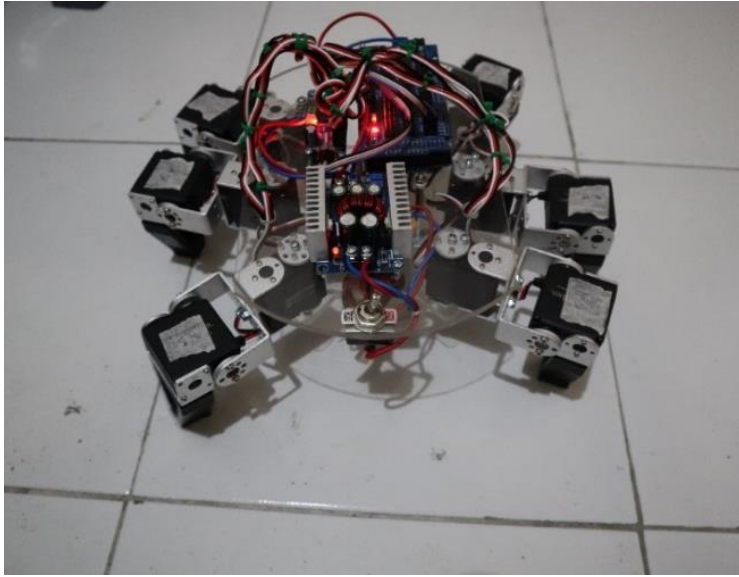

Figure 23. Robot test on the slippery surface

5. Validation of technical experts in the field of robotics.

Technical experts in robotics carry out validation, and this validation aims to determine the success of developing a six-legged robotic motion system from the previous robot. This will be used as a reference for filling out the existing validation sheet. Two lecturers carried out technical validation at Manado State University.

\section{First lecturer validation}

Vecky Poekoel, S.T., M.T., Ph.D. carried out the first validator, he is one of the lecturers in the Department of Electrical Engineering, Faculty of Engineering, Sam Ratulangi University, and is a lecturer in robotics and robotics practice, from the data from the assessment and validation the first lecturer said the development of a six-legged robotic motion system is feasible to use without revision and experiencing improvements from robots previously.

\section{Second lecturer validation}

Dr. Mario T. Parinsi, S.Kom., M.T.I. carried out the second validator, he is one of the lecturers at the Information and Communication Engineering Education Study Program, Faculty of Engineering, Manado State University, and is a lecturer in robotics and robotics practice courses from the data from the assessment and validation the first lecturer said that the development of the six-legged robotic motion system was feasible to use without revision and experience improvements from previous robots.

\section{CONCLUSION}

Using an acrylic material thicker than the previous robot, the frame structure and mechanics of the robot become more robust than the previous robot. Using a double head type servo motor can reduce the amount 
of torque needed for the robot to move so that there may be errors in the driving motor due to torque. Very little unstable. In testing the robot, it was found that the supply of a stable voltage will significantly affect the motion of each motor driving the robot. The robot motion system has improved both in terms of hardware and software.

It should be noted that the voltage supply from the robot must always be stable in order to reduce the risk of errors in the robot control system. The process of making the frame must be exact both in terms of size and the placement of the position of each leg. This is because the position of the foot is shifted a few millimeters from the position that should be able to affect the movement of the robot later, it would be better if the cutting and positioning of the legs This can be done using a $\mathrm{CNC}$ machine or by using a threedimensional printer.

\section{REFERENCES}

D., \& Wahyudi, R. (2015). Kontrol Kecepatan Robot Hexapod Pemadam Api menggunakan Metoda Logika Fuzzy. Jurnal Nasional Teknik Elektro, 4(2), 227. https://doi.org/10.25077/jnte.v4n2.170.2015

Akhtaruzzaman, M., Bt Samsuddin, N. I., Bt Umar, N., \& Rahman, M. (2009). Design and development of a wall climbing robot and its control system. ICCIT 2009 - Proceedings of 2009 12th International Conference on Computer and Information Technology, 309313.

https://doi.org/10.1109/ICCIT.2009.5407120

Brandenbourger, M., Locsin, X., Lerner, E., \& Coulais, C. (2019). Non-reciprocal robotic metamaterials. Nature Communications, 10(1), 1-8. $\quad$ https://doi.org/10.1038/s41467-01912599-3

Budiharto, W. (2006). Belajar Sendiri: Membuat Robot Cerdas. Elex Media Komputindo. https://books.google.com/books?hl=en\&lr=\&i $\mathrm{d}=\_$Ugs0C6egWsC\&oi=fnd\&pg=PR7\&dq=su mber+daya+robotik+di+bidang+industri\&ots= jPUjjSNKye\&sig=_b1LFMhXfEzkf3BjZiDElcpNog

Burgard, W., Fox, D., \& Hennig, D. (1997). Fast gridbased position tracking for mobile robots. Lecture Notes in Computer Science (Including Subseries Lecture Notes in Artificial Intelligence and Lecture Notes in Bioinformatics), 1303, 289-300. https://doi.org/10.1007/3540634932_23

Chen, J., Gao, F., Huang, C., \& Zhao, J. (2019). Whole-body motion planning for a six-legged robot walking on rugged terrain. Applied Sciences (Switzerland), 9(24), 11-13. https://doi.org/10.3390/app9245284

Darwison, Rusydi, I., \& Imran, I. H. (2011). Perancangan dan Pembuatan Sistem Kontrol Kecepatan Servomotor Continous Parallax dengan PID. Teknika, 1. https://ft.unand.ac.id/profil/program/riset/publi kasi

Devjanin, E. A., Gurfinkel, V. S., Gurfinkel, E. V., Kartashev, V. A., Lensky, A. V., Shneider, A. Y., \& Shtilman, L. G. (1983). The six-legged walking robot capable of terrain adaptation. Mechanism and Machine Theory, 18(4), 257260. https://doi.org/10.1016/0094$114 X(83) 90114-3$

Halim, S. (2007). Merancang Mobile Robot Pembawa Objek Menggunakan OOPic-R. In PT Elex Media Komputindo. PT Elex Media Komputindo.

https://books.google.co.id/books?id=_35D5i96 W2IC\&pg=PR4\&lpg=PR4\&dq=Halim, + Sand y.+2007.+"Merancang+Mobile+Robot+Pemba wa+Objek+Menggunakan+OOPic-

R"+PT+Elex+Media+Komputindo,+Jakarta\&s ource $=$ bl\&ots $=\_4 \mathrm{Xp} 9 \mathrm{Rq} 8 \mathrm{bG} \&$ sig $=\mathrm{ACfU} 3 \mathrm{U} 0 \mathrm{t}$ xpEfIHUtHr1eQoawsAFmblyX7g\&hl=id\&sa $=\mathrm{X} \&$

Kadir, A. (2013). Panduan Praktis Memplajari Aplikasi Mikrokontroler dan Pemogramannya Menggunakan Arduino. In Andi Komputindo (Vol. 8, Issue 1). Andi Offset.

Maulana, R. H. (n.d.). Penerapan Behavior Based Robotic Pada Sistem Navigasi Dan Kontrol Robot Soccer.

Molenda, M. (2003). In search of the elusive ADDIE model. Performance Improvement, 42(5), 3436. https://doi.org/10.1002/pfi.4930420508

Puspresnas. (2019). Ajang Talenta Dikti. Puspresnas Kemdikbud.

https://pusatprestasinasional.kemdikbud.go.id/ jenjang/dikti

Ramadhan, M. F. (2017). Perancangan Kontrol Stabilitas Hexapod Robot Menggunakan 
Metode Neuro-Fuzzy.

http://repository.its.ac.id/44113/

Sethi, S. P., Sriskandarajah, C., Sorger, G., Blazewicz, J., \& Kubiak, W. (1992). Sequencing of parts and robot moves in a robotic cell. International Journal of Flexible Manufacturing Systems, 4(3-4), 331-358. https://doi.org/10.1007/BF01324886

Soyguder, S., \& Alli, H. (2007). Design and prototype of a six-legged walking insect robot. Industrial Robot, 34(5), 412-422. https://doi.org/10.1108/01439910710774412

Utama, A. W. T. (2018). Pengembangan Sistem Robot Berkaki Enam(Hexapod) Menggunakan Metode Behavior Based Control pada Kontes Robot Pemadam Api Berkaki.

Zhang, J., Wang, Y., \& Xiong, R. (2016). Industrial robot programming by demonstration. ICARM 2016 - 2016 International Conference on Advanced Robotics and Mechatronics, 300305.

https://doi.org/10.1109/ICARM.2016.7606936 